\title{
PENGARUH STRES KERJA TERHADAP KINERJA KARYAWAN PT. PLN (PERSERO) AREA JAMBI RAYON TELANAIPURA
}

\author{
Muhammad Aulia \\ Karyawan PT.PLN (Persero), Supervisor Konstruksi UP3 Jambi \\ baraaulia54@gmail.com
}

\begin{abstract}
Abstrak
Tujuan penelitian ini adalah untuk mengetahui bagaimana stres kerja dan kinerja karyawan di PT.PLN Rayon Telanaipura Jambi dan menganalisis pengaruh stres kerja terhadap kinerja karyawan PT.PLN Rayon Telanaipura Jambi. Seluruh karyawan berjumlah 45 orang dijadikan responden. Melalui penyebaran kuesioner data dikupulkan. Pengolahan data dilakukan dengan menggunakan SPPS 16. Hasil penelitian menunjukkan bahwa tingkat stres kerja berada pada kategori cukup tinggi dan tingkat kinerja karyawan berada pada kategori cukup tinggi. Stres kerja mempunyai hubungan positif dengan kinerja pegawai yang ditunjukkan oleh koefisien variabel dimana faktor stres kerja bertanda positif. Uji signifikansi berdasarkan uji t antara variabel stres kerja dengan variabel kinerja karyawan menunjukkan bahwa stres kerja berpengaruh signifikan terhadap kinerja karyawan PT.PLN (Persero) Rayon Telanaipura Jambi.
\end{abstract}

Kata Kunci : stress kerja, kinerja karyawan

\begin{abstract}
The purpose of this study was to determine how work stress and employee performance at PT PLN Rayon Telanaipura Jambi and to analyze the effect of job stress on employee performance at PT PLN Rayon Telanaipura Jambi. All 45 employees were made respondents. Through the distribution of questionnaires the data was collected. Data processing was carried out using SPPS 16. The results showed that the level of work stress was in the high enough category and the employee's performance level was in the high enough category. Job stress has a positive relationship with employee performance as indicated by the variable coefficient where the work stress factor is positive. The significance test based on the $t$ test between work stress variables and employee performance variables shows that job stress has a significant effect on the employee performance of PT PLN (Persero) Rayon Telanaipura Jambi.
\end{abstract}

Keywords: job stress, employee performance

\section{PENDAHULUAN}

Sejalan dengan perkembangan zaman, berbagai macam tantangan kehidupan yang dihadapi oleh individu menyebabkan tekanan-tekanan hidup baik fisik maupun emosional meningkat, begitu pula apabila seseorang berprofesi sebagai karyawan. Kegiatan-kegiatan dan beban kerja yang setiap hari dilakukan karyawan merupakan salah satu diantara tantangan kehidupan. Selain tekanan yang berasal dari lingkungan kerja, lingkungan keluarga dan lingkungan sosial juga sangat berpotensial menimbulkan kecemasan. Dampak yang sangat merugikan dari adanya gangguan kecemasan yang sering dialami karyawan disebut stres.

Anoraga (2005) menjelaskan bahwa stres merupakan suatu bentuk tanggapan seseorang, baik fisik maupun mental terhadap suatu perubahan di lingkungannya yang dirasakan mengganggu dan mengakibatkan dirinya terancam. Jika dihubungkan dengan 
pekerjaan maka masalah stres pada dasarnya sering dikaitkan stres yang terjadi di lingkungan pekerjaan, yaitu dalam proses interaksi antara seorang karyawan dengan aspek-aspek pekerjaannya dan posisinya sangat penting dalam kaitannya dengan produktifitas kinerja karyawan. Kinerja di dalam perusahaan dilakukan oleh segenap sumber daya manusia dalam organisasi, baik unsur pimpinan maupun pekerja Mangkunegara (2005)menjelaskan salah satu faktor yang mempengaruhi tingkat keberhasilan suatu organisasi adalah kinerja karyawannya.Sehingga penting untuk selalu meninjau faktor-faktor yang berpengaruh terhadap kinerja karyawan.

PT.Perusahaan Listrik Negara (PLN-Persero) sebagai satu-satunya perusahaan BUMN yang memiliki otoritas tunggal terhadap masalah listrik, PLN jelas dihadapkan dengan berbagai tantangan dan dinamika pelistrikan. PLN dituntut untuk memberikan kinerja pelayanan yang terbaik kepada masyarakat pengguna listrik. Pemadaman listrik menjadi pertimbangan untuk diamati, dikarenakan pemadaman listrik menjadi keluhan masyarakat termasuk terjadinya kerusakan gardu, korslet arus pendek, pemadaman bergilir secara langsung ataupun tidak langsung merugikan masyarakat sebagai konsumen pengguna jasa listrik.

Selain dari masyarakat, keluhan juga disuarakan oleh karyawan sendiri. Target permintaan pemasangan listrik baru turut mempengaruhi kinerja karyawan PT.PLN (Persero) Rayon Telanaipura, seperti yang terlihat pada Tabel 1 dibawah ini.

Tabel 1

Daftar Jumlah Keluhan Karyawan dan Kinerja Teknis PT.PLN (Persero) Rayon Telanaipura Periode Tahun 2009 -2013

\begin{tabular}{|c|c|c|c|c|c|c|c|c|c|c|}
\hline \multirow{4}{*}{ Thn } & \multicolumn{2}{|c|}{ Jumlah } & \multicolumn{8}{|c|}{ Kinerja Teknis } \\
\hline & \multirow{2}{*}{ Karyawan } & \multirow{2}{*}{$\begin{array}{c}\text { Keluhan } \\
\text { Karyawan }\end{array}$} & \multicolumn{4}{|c|}{ Target } & \multicolumn{4}{|c|}{ Realisasi } \\
\hline & & & \multicolumn{4}{|c|}{ Indikator } & \multicolumn{4}{|c|}{ Indikator } \\
\hline & (org) & (kasus) & $\begin{array}{c}\text { SAIDI } \\
(\mathrm{mnt})\end{array}$ & $\begin{array}{c}\text { SAIFI } \\
\text { (kali) }\end{array}$ & $\begin{array}{c}\text { Trafo } \\
\text { Rusak } \\
\text { (bh) }\end{array}$ & $\begin{array}{c}\text { Losses } \\
(\%)\end{array}$ & $\begin{array}{c}\text { SAIDI } \\
(\mathrm{mnt})\end{array}$ & $\begin{array}{c}\text { SAIFI } \\
\text { (kali) }\end{array}$ & $\begin{array}{c}\text { Trafo } \\
\text { Rusak } \\
\text { (bh) }\end{array}$ & $\begin{array}{c}\text { Losses } \\
(\%)\end{array}$ \\
\hline 2009 & 32 & 13 & 90,56 & 3,29 & 2,86 & 7,43 & 73,6 & 2,76 & 3,2 & 7,42 \\
\hline 2010 & 35 & 16 & 34,79 & 1,95 & 1,51 & 6,18 & 33,75 & 1,00 & 1,40 & 8,12 \\
\hline 2011 & 39 & 21 & 299,14 & 5,48 & 2,60 & 7,41 & 80,47 & 2,22 & 2,49 & 11,5 \\
\hline 2012 & 41 & 19 & 58 & 1,88 & 1,73 & 8,00 & 49,00 & 1,72 & 1,69 & 10,8 \\
\hline 2013 & 45 & 27 & 701,40 & 28,50 & 1,20 & 7,95 & 701,42 & 28,53 & 1,10 & 10,92 \\
\hline
\end{tabular}

Sumber: data diolah dari tahun 2009-2013

Ket:

SAIDI: System Average Interruption Duration Index (Lama Padam Rata-rata Konsumen)

SAIFI: System Average Interruption Frequency Index (Frekuensi Padam Rata-rata Konsumen)

Pada tahun 2009 dapat dilihat bahwa keluhan karyawan mencapai 13 kasus. Sedangkan aspek kinerja teknis dapat dilihat dari perbandingan antara target pemasangan dan realisasinya apakah tercapai/tidak tercapai. Di tahun 2009 terlihat bahwa target kinerja dengan indikator SAIDI,SAIFI,dan losses ketiganya tidak tercapai, namun target trafo rusak tercapai. Target pemasangan yang cukup tinggi menyebabkan realisasi pemasangan dari aspek kinerja teknis banyak yang tidak tercapai. Sehingga berpengaruh pada tingkat ketidakhadiran para pegawai PT.PLN Persero Area Telanaipura yang dapat kita lihat pada tabel 2 berikut ini: 
Tabel 2

Daftar Absensi Karyawan PT.PLN (Persero) Area Jambi Rayon Telanaipura Periode Tahun 2009-2013

\begin{tabular}{|c|c|c|c|c|}
\hline \multirow{2}{*}{ Thn } & \multicolumn{4}{|c|}{ Ketidakhadiran karyawan } \\
\cline { 2 - 5 } & Cuti (kasus) & Sakit (kasus) & Izin (kasus) & Alfa (kasus) \\
\hline 2009 & 16 & 9 & 14 & 6 \\
\hline 2010 & 19 & 17 & 29 & 13 \\
\hline 2011 & 21 & 13 & 33 & 18 \\
\hline 2012 & 25 & 20 & 36 & 22 \\
\hline 2013 & 27 & 25 & 40 & 28 \\
\hline
\end{tabular}

Sumber: data diolah dari tahun 2009-2013

Pada tabel di atas ketidakhadiran difokuskan kepada para karyawan yang mengambil izin cuti liburan dan tanpa keterangan (alfa). Dari tabel dapat kita lihat bahwa izin cuti liburan meningkat dari 16 kasus pada tahun 2009 menjadi 19 kasus di tahun 2010. Kemudian terus meningkat pada tahun 2011, 2012 dan 2013 secara berturut-turut sebesar 21, 25 dan 27 kasus. Sedangkan ketidakhadiran tanpa keterangan (alfa) di tahun 2009 sebanyak 6 kasus, meningkat menjadi 13 kasus pada tahun 2010 dan 18 kasus di tahun 2011. Pada tahun 2012 ada 22 kasus ketidakhadiran tanpa keterangan dan meningkat sebanyak 4 kasus menjadi 28 kasus di tahun 2013.

Jumlah kehadiran karyawan yang tiap tahun semakin menurun diduga akibat tingkat stres yang meningkat. Hal ini menjelaskan bahwa keberhasilan bisnis PT.PLN adalah berusaha menawarkan kualitas jasa pelayanan tinggi dalam pengelolaan listrik untuk memenuhi kebutuhan listrik masyarakat rumah tangga dan listrik perusahaan/industri setiap hari, yang nampak dalam kinerja yang ada. Berdasarkan uraian diatas, maka peneliti ingin meneliti mengenai bagaimana stres kerja dan kinerja karyawan di PT.PLN Rayon Telanaipura Jambi dan pengaruh stres kerja terhadap kinerja karyawan di PT.PLN Rayon Telanaipura Jambi.

\section{KAJIAN PUSTAKA \\ Stres Kerja}

Anderson (2003) menjelaskan stres kerja adalah suatu perasaan yang menekan atau rasa tertekan yang dialami karyawan dalam menghadapi pekerjaannya. Lebih lanjut Anderson (2003) menjelaskan "Job stres refers to a physical or psychological deviation from the normal human state that is caused by stimuli in the work environment" yang kurang lebih memiliki arti suatu tekanan akibat bekerja juga akan mempengaruhi emosi, proses berpikir dan kondisi fisik seseorang, di mana tekanan itu berasal dari lingkungan pekerjaan tempat individu tersebut berada. Sehingga indikator stres kerja yang digunakan dalam penelitian ini berdasarkan Hurrel,et.al (1988) yaitu :

1.Tuntutan tugas yaitu kemampuan menjalankan tugas kerja dengan baik

2. Lingkungan kerja yaitu ketersediaan alat dan perlengkapan kerja, nuansa kerja yang kondusif dan keharmonisan kerja antar karyawan.

3. Konflik peran yaitu ketidakjelasan peran seseorang dalam organisasi yang disebabkan oleh tidak adanya arahan yang jelas dari pihak manajemen. 


\section{Kinerja Karyawan}

Mangkunegara (2005) kinerja adalah kumpulan dari serangkaian hasil kerja menurut kuantitas, kualitas, efisiensi dan efektivitas kerja dalam mencapai tujuan. Sementara itu, dalam kaitannya dengan indikator kinerja karyawan, Simamora (2007) mengemukakan bahwa kinerja karyawan dapat diukur dengan indikator-indikator sebagai berikut :

1. Kualitas Kerja yaitu wujud perilaku atau kegiatan yang dilaksanakan sesuai dengan harapan dan kebutuhan atau tujuan yang dicapai secara efektif dan efisien."

2. Kuantitas Kerja jumlah pekerjaan yang harus diselesaikan atau dicapai.

3. Tepat Waktu yaitu pemenuhan kesesuaian waktu yang dibutuhkan atau diharapkan dalam pelaksanaan kegiatan.

\section{METODE PENELITIAN}

Jenis penelitian adalah explanatory research yang dilakukan untuk mengetahui kejadian dan menghubungan keterkaitan objek yang diteliti. Bentuk penelitian ini adalah deskriptif kausatif yang bertujuan untuk melihat sebab/akibat atau pengaruh pada variabel variabel penelitian. Analisis menggunakan pendekatan kuantitatif, yaitu mengumpulkan instrumen penelitian dan menguji hipotesis secara statistik (Sugiyono, 2006)

Populasi penelitian ini berjumlah 45 orang dan kesemuanya dijadikan sampel (full sample). Teknik pengumpulan data menggunakan dua teknik yaitu; 1.) Kuesioner yaitu pengumpulan data dengan cara menyebarkan daftar pertanyaan tentang stres kerja dan kinerja karyawan, 2) Observasi yaitu mengamati objek secara langsung di tempat penelitian. Alat analisis yang digunakan menggunakan analisis regresi sederhana. Olah data dilakukan dengan menggunakan software SPSS 16.

\section{HASIL DAN PEMBAHASAN}

Pengisian kuesioner diukur dengan menggunakan skala Likert dengan lima poin. Sangat setuju $=5$, setuju $=4$, ragu-ragu $=3$, tidak setuju $=2$, sangat tidak setuju $=1$. Kemudian hasil jawaban responden dihitung rentang skalanya dan dikelompokkan sesuai dengan kategori dalam tabel berikut:

Tabel 3 Rentang skala penilaian

\begin{tabular}{|c|c|}
\hline Kriteria Jawaban & Bobot Nilai \\
\hline Sangat Rendah & $45-80$ \\
\hline Rendah & $81-116$ \\
\hline Cukup Tinggi & $117-152$ \\
\hline Tinggi & $153-188$ \\
\hline Sangat Tinggi & $189-225$ \\
\hline
\end{tabular}


Berikut tabel hasil tanggapan responden:

Tabel 4

Tanggapan Responden Terhadap Variabel Stres Keria

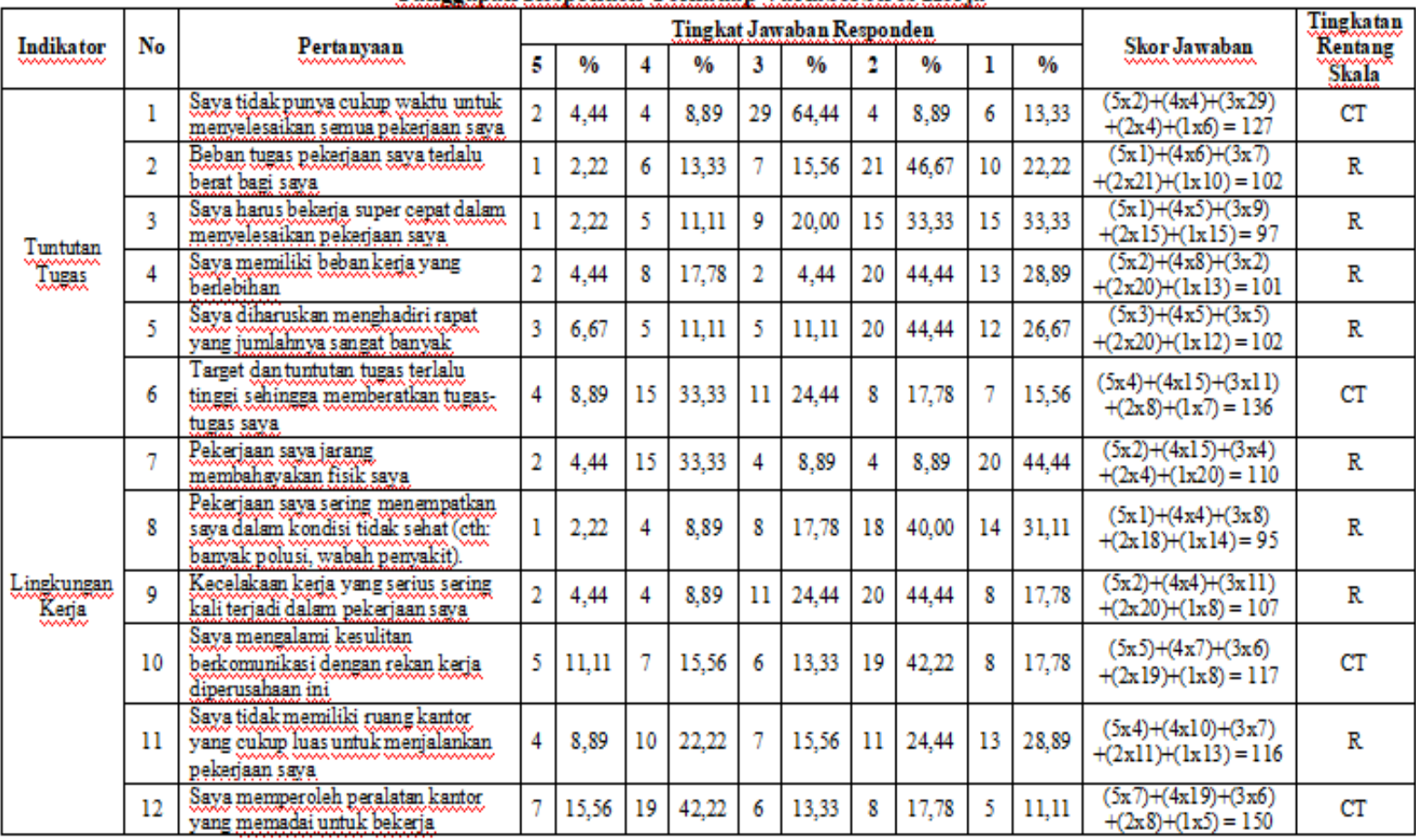

\begin{tabular}{|c|c|c|c|c|c|c|c|c|c|c|c|c|c|c|}
\hline \multirow{2}{*}{ Indikator } & \multirow[t]{2}{*}{ No } & \multirow{2}{*}{ Pertanyaan } & \multicolumn{10}{|c|}{ Tingkat Jawaban Responden } & \multirow{2}{*}{ Skor Jawaban } & \multirow{2}{*}{$\begin{array}{l}\text { Tingkatan } \\
\text { Rentang } \\
\text { SThala } \\
\text { SThal }\end{array}$} \\
\hline & & & 5 & $\%$ & 4 & $\%$ & 3 & $\%$ & 2 & $\%$ & 1 & $\%$ & & \\
\hline \multirow{3}{*}{$\begin{array}{l}\text { Lingkungan } \\
\text { Kerja }\end{array}$} & 13 & $\begin{array}{l}\text { Saya mendapat dukungan layanan } \\
\text { yang culum untuk melaksanakan } \\
\text { pekejasan saya }\end{array}$ & 9 & 20,00 & 16 & 35,56 & 13 & 28,89 & 3 & 6,67 & 4 & 8,89 & $\begin{array}{l}(5 \times 9)+(4 \times 16)+(3 \times 13 \\
)+(2 \times 3)+(1 \times 4)=158\end{array}$ & $\mathrm{~T}$ \\
\hline & 14 & 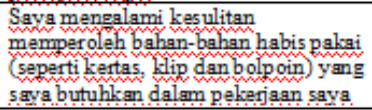 & 7 & 15,56 & 9 & 20,00 & 5 & 11,11 & 22 & 48,89 & 2 & 4,44 & $\begin{array}{c}(5 \times 7)+(4 \times 9)+(3 \times 5) \\
+(2 \times 22)+(1 \times 2)=132\end{array}$ & CT \\
\hline & 15 & $\begin{array}{l}\text { Alat-alat kantor yang saya butuhkan } \\
\text { untuk menjalankan pekerjaan sering } \\
\text { kali rusak atau tidak berfungsi }\end{array}$ & 5 & 11,11 & 8 & 17,78 & 15 & 33,33 & 11 & 24,44 & 6 & 13,33 & $\begin{array}{l}(5 \times 5)+(4 \times 8)+(3 \times 15) \\
+(2 \times 11)+(1 \times 6)=130\end{array}$ & CT \\
\hline \multirow{5}{*}{$\begin{array}{l}\text { Konflik } \\
\text { Peran } \\
\text { Peran }\end{array}$} & 16 & $\begin{array}{l}\text { Pekerjaan saya punya jumlah konflik } \\
\text { yang besaryang banyak memmntut } \\
\text { saya }\end{array}$ & 2 & 4,44 & 7 & 15,56 & 7 & 15,56 & 20 & 44,44 & 9 & 20,00 & $\begin{array}{c}(5 \times 2)+(4 \times 7)+(3 \times 7) \\
+(2 \times 20)+(1 \times 9)=108\end{array}$ & $\mathrm{R}$ \\
\hline & 17 & $\begin{array}{l}\text { Saya tidak tahu apa yang menjadi } \\
\text { tanngungiawab pekerjaan yang saya } \\
\text { jalankan }\end{array}$ & 7 & 15,56 & 10 & 22,22 & 6 & 13,33 & 18 & 40,00 & 4 & 8,89 & $\begin{array}{l}(5 \times 7)+(4 \times 10)+(3 \times 6) \\
+(2 \times 18)+(1 \times 4)=133\end{array}$ & CT \\
\hline & 18 & $\begin{array}{l}\text { Saya tidak tahu dengan pasti apa } \\
\text { yang dihargon kan perus ahas dan saya } \\
\text { sehubungan denganposisi pekeriagn } \\
\text { yang saya terima }\end{array}$ & 6 & 13,33 & 19 & 42,22 & 10 & 22,22 & 5 & 11,11 & 5 & 11,11 & $\begin{array}{c}(5 \times 6)+(4 \times 19)+(3 \times 10) \\
+(2 \times 5)+(1 \times 5)=151\end{array}$ & CT \\
\hline & 19 & 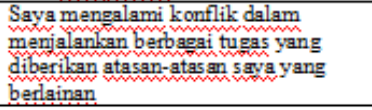 & 5 & 11,11 & 19 & 42,22 & 11 & 24,44 & 8 & 17,78 & 2 & 4,44 & $\begin{array}{c}(5 \times 5)+(4 \times 19)+(3 \times 11) \\
+(2 \times 8)+(1 \times 2)=152\end{array}$ & CT \\
\hline & 20 & $\begin{array}{l}\text { Saya merasalas konflik dari tugas } \\
\text { peleriaan yang dibebankan atasan } \\
\text { langsung saya }\end{array}$ & 5 & 11,11 & 14 & 31,11 & 7 & 15,56 & 14 & 31,11 & 5 & 11,11 & $\begin{array}{l}(5 \times 5)+(4 \times 14)+(3 \times 7) \\
+(2 \times 14)+(1 \times 5)=135\end{array}$ & CT \\
\hline \multicolumn{13}{|c|}{ Total Skor } & 2459 & \multirow{2}{*}{ CT } \\
\hline \multicolumn{13}{|c|}{ Rata-rata } & 122,95 & \\
\hline
\end{tabular}

Dari tabel hasil tanggapan responden dapat dilihat bahwa nilai total skor sebesar 2459 dengan rata-rata 122,95 yang menempatkan tingkat stres kerja berada pada kategori cukup rendah. 
Tabel 4

Tanggapan Responden Terhadap Variabel Kinerja Karyawan

\begin{tabular}{|c|c|c|c|c|c|c|c|c|c|c|c|c|c|}
\hline \multirow{2}{*}{ No } & \multirow{2}{*}{ Pertanyaan } & \multicolumn{10}{|c|}{ Tingkat Jawaban Responden } & \multirow{2}{*}{ Skor Jawaban } & \multirow{2}{*}{\begin{tabular}{|l} 
Tingkatan \\
Rentang \\
Skala \\
Skala \\
\end{tabular}} \\
\hline & & 5 & $\%$ & 4 & $\%$ & 3 & $\%$ & 2 & $\%$ & 1 & $\%$ & & \\
\hline 1 & $\begin{array}{l}\text { Saya berusaha dengan serius menveles aikan } \\
\text { pekerjaan sampai tuntas }\end{array}$ & 2 & 4,44 & 22 & 48,89 & 6 & 13,33 & 10 & 22,22 & 5 & 11,11 & $\begin{array}{l}(5 \times 2)+(4 \times 22)+(3 \times 6)+(2 \times 10)+(1 \times 5) \\
=141\end{array}$ & CT \\
\hline 2 & $\begin{array}{l}\text { Saya menunjukkan rasa tidak enak } \\
\text { (misalnva sumgkan, malu) jika pekerjagn } \\
\text { belum selesagi. }\end{array}$ & 3 & 6,67 & 16 & 35,56 & 12 & 26,67 & 12 & 26,67 & 2 & 4,44 & $\begin{array}{l}(5 \times 3)+(4 \times 16)+(3 \times 12)+(2 \times 12)+(1 \times 2) \\
=141\end{array}$ & CT \\
\hline 3 & $\begin{array}{l}\text { Saya melapor dengan atasan jika ada } \\
\text { masalah pekerjagn }\end{array}$ & 5 & 11,11 & 10 & 22,22 & 18 & 40,00 & 9 & 20,00 & 3 & 6,67 & $\begin{array}{l}(5 \times 5)+(4 \times 10)+(3 \times 18)+(2 \times 9)+(1 \times 3) \\
=140\end{array}$ & CT \\
\hline 4 & $\begin{array}{l}\text { Saya menunjukkan semangat atau berus aha } \\
\text { memberikan hasil kerja sebaik mungkin } \\
\text { member mank }\end{array}$ & 1 & 2,22 & 20 & 44,44 & 13 & 28,89 & 8 & 17,78 & 3 & 6,67 & $\begin{array}{l}(5 \times 1)+(4 \times 20)+(3 \times 13)+(2 \times 8)+(1 \times 3) \\
=143\end{array}$ & CT \\
\hline 5 & $\begin{array}{l}\text { Saya berusaha memberikan kepuasan kepada } \\
\text { pelanggan }\end{array}$ & 3 & 6,67 & 20 & 44,44 & 13 & 28,89 & 6 & 13,33 & 3 & 6,67 & $\begin{array}{l}(5 \times 3)+(4 \times 20)+(3 \times 13)+(2 \times 6)+(1 \times 3) \\
=149\end{array}$ & CT \\
\hline 6 & $\begin{array}{l}\text { Saya memenuhi standar kerja yang } \\
\text { ditentukan }\end{array}$ & 3 & 6,67 & 20 & 44,44 & 12 & 26,67 & 8 & 17,78 & 2 & 4,44 & $\begin{array}{l}(5 \times 3)+(4 \times 20)+(3 \times 12)+(2 \times 8)+(1 \times 2) \\
=149\end{array}$ & CT \\
\hline 7 & $\begin{array}{l}\text { Saya menveles aikan jumlah hasil kerja } \\
\text { memenuhi tuntutan yang diharapkan } \\
\text { mementane }\end{array}$ & 4 & 8,89 & 23 & 51,11 & 8 & 17,78 & 7 & 15,56 & 3 & 6,67 & $\begin{array}{l}(5 \times 4)+(4 \times 23)+(3 \times 8)+(2 \times 7)+(1 \times 3) \\
=153\end{array}$ & $\mathrm{~T}$ \\
\hline 8 & Saya menveles aikan tugas tepat waktu & 4 & 8,89 & 18 & 40,00 & 12 & 26,67 & 8 & 17,78 & 3 & 6,67 & $\begin{array}{l}(5 \times 4)+(4 \times 18)+(3 \times 12)+(2 \times 8)+(1 \times 3) \\
=147\end{array}$ & $\mathrm{CT}$ \\
\hline 9 & $\begin{array}{l}\text { Saya tidak suka menunda-nunda pekerjaan } \\
\text { yang harus diselesaikan }\end{array}$ & 1 & 2,22 & 22 & 48,89 & 9 & 20,00 & 12 & 26,67 & 1 & 2,22 & $\begin{array}{l}(5 \times 1)+(4 \times 22)+(3 \times 9)+(2 \times 12)+(1 \times 1) \\
=145\end{array}$ & CT \\
\hline 10 & Saya tepat waktu tiba dikantor & 2 & 4,44 & 15 & 33,33 & 11 & 24,44 & 13 & 28,89 & 4 & 8,89 & $\begin{array}{l}(5 \times 2)+(4 \times 15)+(3 \times 11)+(2 \times 13)+(1 \times 4) \\
=133\end{array}$ & CT \\
\hline \multicolumn{12}{|c|}{ Total Skor } & 1441 & \multirow{2}{*}{ CT } \\
\hline \multicolumn{12}{|c|}{ Rata-Rata } & 144,1 & \\
\hline
\end{tabular}

Dari tabel hasil tanggapan responden dapat dilihat bahwa nilai total skor sebesar 1441 dengan rata-rata 144,1 yang menempatkan tingkat kinerja karyawan berada pada kategori cukup tinggi.

\section{Hasil Uji Hipotesis}

Dari hasil analisis regresi linier sederhana dengan bantuan SPP 16 dikethui nilai koefisien regresi, nilai koefisien korelasi dan uji t sebagai berikut:

Nilai Koefisien Regresi

Coefficients $^{\mathrm{a}}$

\begin{tabular}{|cc|c|c|c|c|c|}
\hline \multirow{2}{*}{} & \multirow{2}{*}{ Model } & \multicolumn{2}{|c|}{ Unstandardized Coefficients } & $\begin{array}{c}\text { Standardized } \\
\text { Coefficients }\end{array}$ & & \\
\cline { 3 - 5 } & (Constant) & 1.197 & .189 & & $\mathrm{t}$ & Sig. \\
\hline \multirow{2}{*}{1} & B & Std. Error & Beta & & 6.343 & .000 \\
& STRES KERJA & .719 & .075 & .827 & 9.647 & .000 \\
\hline
\end{tabular}

a. Dependent Variable: KINERJA KARYAWAN

Sehingga diperoleh persamaan regresinya adalah sebagai berikut : $Y=\mathbf{1 , 1 9 7}+$ 0,719X. Nilai koefisien yang positif artinya apabila terjadi perubahan pada variabel $X$, akan menyebabkan perubahan secara searah pada variabel Y. Berdasarkan uraian tersebut dapat disimpulkan bahwa stres kerja memiliki hubungan yang positif atau berpengaruh terhadap kinerja karyawan PT. PLN (Persero) Rayon Telanaipura Jambi.

Selanjutnya untuk mengetahui besarnya pengaruh antara variabel independent terhadap variabel dependent, maka digunakan analisis koefisien korelasi dengan melihat nilai $R$-square. 
Nilai Koefisien Korelasi

Model Summary

\begin{tabular}{|c|c|c|c|c|}
\hline Model & $\mathrm{R}$ & R Square & Adjusted R Square & $\begin{array}{c}\text { Std. Error of the } \\
\text { Estimate }\end{array}$ \\
\hline 1 & $.827^{\mathrm{a}}$ & .684 & .677 & .31177 \\
\hline
\end{tabular}

a. Predictors: (Constant), STRES KERJA

Berdasarkan tabel hasil koefisien korelasi terlihat nilai koefisien korelasi sebesar (R) $=0.827$ dan jika dipersentasekan diperoleh hasil sebesar 82,7\%. yang menunjukkan bahwa hubungan antara variabel stres kerja (X) dan kinerja karayawan (Y) adalah sangat erat. Sedangkan nilai koefisien determinasi atau $\mathrm{R}$ Square $=0.684$ menunjukkan $68,4 \%$ variabel kinerja karyawan dapat dijelaskan oleh variabel stres kerja, sedangkan sisanya $31,6 \%$ dipengaruhi oleh variabel lain yang tidak diteliti.

Uji $t$ berpengaruh signifikan apabila hasil perhitungan $t_{\text {hitung }}$ lebih besar dari $t_{\text {tabel }}(t$ hitung $\left.>\mathrm{t}_{\text {tabel }}\right)$ atau probabilitas kesalahan lebih kecil dari 5\% $(\mathrm{p}<0.05)$. Dari tabel ekonometrika didapat bahwa nilai $t_{\text {tabel }}=2.01$ dimana $(\alpha=0.05$ dan $\mathrm{df}=43)$

\section{Hasil Perhitungan Uji t}

Coefficients $^{\mathrm{a}}$

\begin{tabular}{|cc|c|c|c|c|c|}
\hline \multirow{2}{*}{ Model } & \multicolumn{2}{|c|}{$\begin{array}{c}\text { Unstandardized } \\
\text { Coefficients }\end{array}$} & $\begin{array}{c}\text { Standardized } \\
\text { Coefficients }\end{array}$ & & \\
\cline { 3 - 5 } & (Constant) & 1.197 & .189 & & $\mathrm{t}$ & Sig. \\
\hline 1 & B & Std. Error & Beta & 6.343 & .000 \\
& STRES KERJA & .719 & .075 & .827 & 9.647 & .000 \\
\hline
\end{tabular}

a. Dependent Variable: KINERJA KARYAWAN

Hasil pengujian variabel independen stres kerja terhadap kinerja karyawan PT. PLN (Persero) Rayon Telanaipura menunjukkan nilai koefisien regresi sebesar (B) sebesar 0.719 dengan $t_{\text {hitung }}=9.647$ dan $t_{\text {tabel }}=2.01$ maka $t_{\text {hitung }}>t_{\text {tabel }}$ yang berarti memiliki pengaruh signifikan dengan tingkat probabilitas atau Sig $=0.000$ yang lebih kecil dari 0,05 . Hal ini menunjukkan bahwa stres kerja berpengaruh positif dan signifikan terhadap kinerja karyawan. Dengan demikian Ho ditolak dan Ha diterima.

\section{Pembahasan}

Kenyataan yang ditemukan dari karyawan bahwa tuntutan kerja yang ketat menjadikan banyak karyawan menjadi cukup stres ( kategori cukup tinggi) dalam menghadapi dinamika kerja, yang menjadikan karyawan kurang mematuhi komitmen terhadap aturan kerja, khususnya yang berkaitan dengan tingkat kehadiran karyawan. Namun, di sisi lain karyawan menanggapi tuntutan kerja yang tinggi tersebut dengan sikap-sikap positif yang menyebabkan kinerja karyawan berada di kategoti cukup tinggi, walaupun realisasi dari target-target pencapaian yang telah perusahaan berikan tidak sepenuhnya tercapai. Dengan kata lain stres kerja dalam bentuk tuntutan kerja yang semula negatif diubah menjadi energi aktual yang memiliki nilai positif oleh para karyawan. 
Hal tersebut sejalan dengan teori yang dikemukakan oleh Quick dan Quick (1984) seperti yang dikutip dari (Budilaksono 2013)yang mengkategorikan jenis stress menjadi dua yaitu:

1. Eustress, yaitu hasil dari respon terhadap stres yang bersifat sehat, positif, dan konstruktif (bersifat membangun). Hal tersebut termasuk kesejahteraan individu dan juga organisasi yang diasosiasikan dengan pertumbuhan, fleksibilitas, kemampuan adaptasi, dan tingkat performance yang tinggi.

2. Distress, yaitu hasil dari respon terhadap stres yang bersifat tidak sehat, negatif, dan destruktif (bersifat merusak). Hal tersebut termasuk konsekuensi individu dan juga organisasi seperti penyakit kardiovaskular dan tingkat ketidakhadiran (absenteeism) yang tinggi, yang diasosiasikan dengan keadaan sakit, penurunan, dan kematian.

Menjamin terciptanya nuansa kerja yang kondusif dalam beraktivitas kerja, maka karyawan akan termotivasi dengan adanya tingkat keamanan dan keselamatan kerja atas suasana kerja yang baik. Bila suasana kerja sering mengalami kebisingan, keributan, suasana lalu lalang orang, tentunya menganggu konsentrasi karyawan dalam menjalankan tugas pokok dan fungsinya dengan baik. Akibatnya banyak pekerjaan yang terbengkalai dan hal ini akan memberikan dampak rendahnya peningkatan kinerja karyawan. Oleh karena itu pengelolaan stress dalam perusahaan sangatlah penting dimana karyawan maupun perusahaan akan mengalami dampak dari stres tersebut.

\section{KESIMPULAN}

Berdasarkan analisis data dan pembahasan hasil penelitian, dapat ditarik kesimpulan sebagai berikut:

1. Tingkat stres kerja dengan nilai rata-rata 122,95 berada pada kategori cukup tinggi dan tingkat kinerja karyawan dengan nilai rata-rata 144,1 berada pada kategori cukup tinggi.

2. Hasil uji t menunjukkan nilai $t_{\text {hitung }}$ sebesar 9,647 ,koefisien regresi sebesar 0,719 dan nilai probabilitas sebesar 0,000 yang lebih kecil dari 0,05 . Hal ini menunjukkan bahwa stres kerja berpengaruh positif dan signifikan terhadap kinerja karyawan. Sedangkan besar pengaruhnya ditunjukkan oleh koefisien regresi sebesar 0,719 yang artinya jika nilai faktor stres kerja mengalami peningkatan sebesar 1\%, maka kinerja karyawan akan meningkat sebesar 0.819

\section{DAFTAR PUSTAKA}

Anderson R. (2003). Stress at Work: The Current Perspective. The Journal of The Royal Society for the Promotion of Health

Anoraga, Panji. 2005. Psikologi Kerja. Rineka Cipta. Jakarta.

Budilaksono, Agung.2013. Sumber, Dampak dan Solusi Stres Pekerjaan. Widyaiswara Pusdiklat Bea dan Cukai.

http://www.bppk.depkeu.go.id/webbc/index.php?option=com_docman\&task=doc_downlo ad\&gid=611\&Itemid=.

Mangkunegara,A.A Anwar Prabu.2005. Manajemen Sumber Daya Manusia Perusahaan. Bandung: PT. Remaja Rosdakarya. (A)

Simamora, Hendry. 2007. Manajemen Sumber Daya Manusia. STIE YKPN. Yogyakarta. Sugiyono, 2005. Metode Penelitian Statistik. Penerbit Gunung Agung, Jakarta. 